\title{
Diffuse Large B-cell Lymphoma Transformed from MALT Lymphoma Presented by Acute Abdomen
}

\section{Akut Batın ile Presente Olan MALT Lenfomadan Transforme Diffuz Büyük B Hücreli Lenfoma}

Güven ÇETIN, Cumali KARATOPRAK, Nidal CEVIRME, Mehmet Ali ÇIKRIKCIOGLU, Muharrem KISKAÇ

Department of Internal Medicine, Bezmialem Vakif University, Faculty of Medicine, Istanbul, Turkey

\section{ABSTRACT}

Non-Hodgkin lymphomas constitute $1 \%$ of gastrointestinal system tumors. Lymphomas can occur from the oral cavity to the rectum. Primary gastrointestinal lymphomas are most frequent in the stomach, followed by the small and large intestines. Here, we report a 41-year-old male patient who had been under chemotherapy following a diagnosis of diffuse large B-cell lymphoma transformed from MALT lymphoma and discuss new treatment options. He presented to us with an acute abdomen. To our knowledge, this was the first case in the literature that presented with acute abdomen and was diagnosed as diffuse large B-cell lymphoma that transformed from MALT lymphoma. In addition, for the treatment, we want to draw attention to the importance of surgery, in addition to chemotherapy.

Key Words: Maltoma, diffuse large B-cell lymphoma, acute abdomen, ileus

\section{ÖZET}

Non-Hodgkin Lenfomalar (NHL) gastrointestinal sistem (GİS) malin tümörlerinin \%1'ini oluşturur. Lenfomalar GİS'in, oral kaviteden rektuma kadar her hangi bir yerinde oluşabilir. Primer gastrointestinal lenfomaların mideden sonra en sık görüldüğü alan ince ve kalın barsaklardır. Akut batın tablosu ile gelen MALT lenfomadan transforme olmuş diffuz büyük B hücreli lenfoma tanısı konularak kemoterapi başlanan 41 yaşındaki erkek hasta sunulmuş ve tedavi seçenekleri tartışılmıştır. Literatürde akut batın tablosu ile gelen ve lenfoma tanısı konulan vakalar içinde MALT lenfomadan transforme olmuş diffuz B hücreli lenfoma tanısına rastlamadık. Ayrıca son yıllarda yapılan çalışmalarda vurgulanan kemoterapinin yanında cerrahinin önemine dikkat çekilmiştir.

Anahtar Sözcükler: Maltoma, diffuz büyük B hüçreli lenfoma, akut batın, ileus

\section{Introduction}

Acute abdominal pain is defined as pain for less than 1 week. A rapid diagnosis is required, since acute abdomen is due to intra-abdominal emergency conditions in many patients (1). Although emergency surgery is commonly required in cases of acute abdomen due to intra-abdominal emergency, emergency surgery may occasionally delay the diagnosis and treatment and may even have negative effects. Among these cases, lymphomas with extra-nodal involvement may be seen. However, an increasing number of recent publications indicate that chemotherapy, added to surgical resection, in local mass lymphoma is more successful than chemotherapy alone (2). These rare cases may occasionally present with abdominal pain, abdominal mass, and acute abdomen. We describe here a patient who had been under chemotherapy due to a diagnosis of diffuse large B-cell lymphoma that transformed from MALT lymphoma and presented with acute abdomen.

\section{Case Report}

A 41-year-old male patient was admitted to the emergency department with complaints of acute abdominal pain, nausea, and vomiting. At the emergency clinic, computerized tomography (CT) with contrast showed diffuse lymphadenopathy and thickening of the wall in the terminal ileum and ascending colon; therefore, the patient was admitted to the surgery ward with a diagnosis of ileus due to malignancy (Figure 1). As the abdominal pain was relieved and feces and gas dis- 

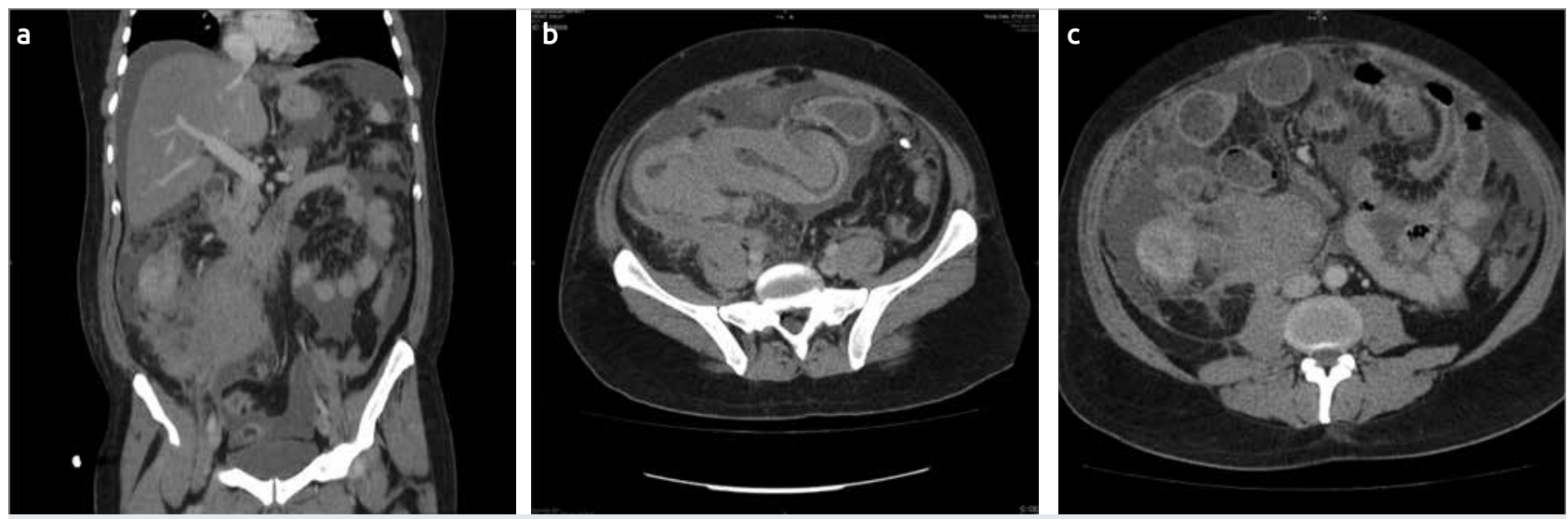

Figure 1. a-c. a. Computed tomography images of lower abdominal, coronal section, b. Axial section, c. Axial section
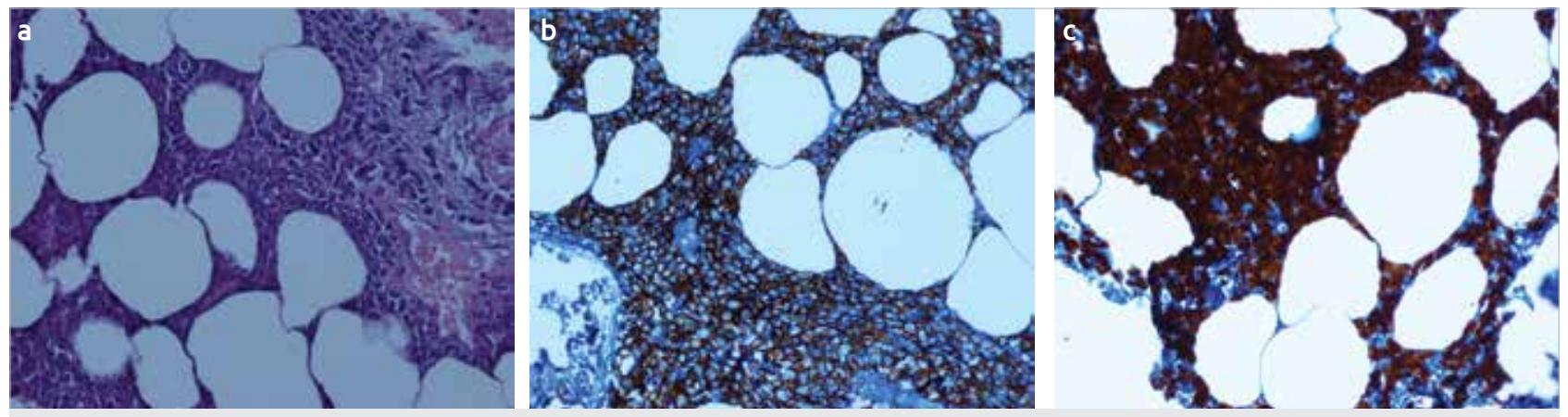

Figure 2. a-c. a. Histopathological images of the intestinal biopsy, hematoxylin-eosin staining;*200, b. Immuno staining, c. Immuno staining remote appearance

charge was initiated, a truncate biopsy was obtained from the colonic mass by colonoscopy and from a mass in the right inferior part of the abdomen. Following the biopsy, he was diagnosed as having diffuse large B-cell lymphoma (DLBCL) that transformed from MALT lymphoma (Figure 2). The patient was then transferred to the hematology clinic.

Examination of the patient disclosed that his general situation was poor: the blood pressure was $90 / 70 \mathrm{~mm} \mathrm{Hg}$, pulse rate was 112 beats $/ \mathrm{min}$, and a palpable mass with irregular contour was present in the right mid-abdominal quadrant. His abdomen was distended, and diffuse acid was present. Both direct X-ray in the standing position and abdominal CT were performed due to the likelihood of perforation, but no sign of perforation was detected. Bone marrow biopsy and positron emission tomography (PET/CT) (hypermetabolic thickening and mass in the terminal ileum, periton, and mesenteric areas and diffuse hypermetabolic lymph nodes) were performed for staging.

A chemotherapy protocol was initiated, consisting of rituximab, cyclophosphamide, doxorubicin, vincristine, and prednisolone (R-CHOP). Following the first chemotherapy dose, a right jugular dialysis catheter was placed for dialysis requirement, since creatinine, uric acid, and phosphorus levels of the patient had increased. Acute deep venous thrombosis (DVT) was detected by Doppler ultrasound (US), which had been performed due to pain and swelling in the left inferior ex- tremity, and treatment of enoxaparin sodium $(12,000$ anti-Xa IU/day) was initiated 3 weeks later. The second chemotherapy cure of R-CHOP was administered. Redness and swelling developed on the left hand side of the patient, and cefoperazone and vancomycin were initiated following consultation with the infectious disease department. DVT also developed in the right inferior extremity. The infection on his left hand did not regress, despite antibiotic treatment. The superficial tissue was evaluated again by US. Thrombosis was detected in the cephalic vein until the mid-arm. Treatment was continued with enoxaparin sodium (12,000 anti Xa IU/day). DVT also developed in the right superior extremity of the patient. A $2.5-\mathrm{cm}$-diameter lesional mass, indicating pericardial lymphoma, intra-abdominal diffuse LAP, and peritoneal lymphomatosis, was detected via tomography. Despite treatment, the size of the lesions increased (hyperdense lobulated solid lesion reaching $7.5^{*} 5 \mathrm{~cm}$ in the last $\mathrm{CT}$ ) and the general status progressively worsened, and after 12 days, the patient died in the intensive care unit due to widespread thrombosis.

\section{Discussion}

Non-Hodgkin lymphomas (NHLs) constitute $1 \%$ of tumors of the gastrointestinal system (GIS) (3). Primary gastrointestinal lymphomas are most frequent in the stomach, followed by the small and large intestines. The most common type of these lymphomas is diffuse large B-cell lymphoma (DLBCL) 
(2). Primary intestinal DLBCL is mainly a localized disease and is most commonly seen in the ileocecal region (2). Initially, 30\%-50\% of small intestine lymphomas present as acute abdomen (3). The ideal treatment of gastrointestinal lymphomas is a controversial subject and is related to the stage of the disease and its histological type (3). Surgical resection may play an important role in the diagnosis and treatment of NHL localized in the GIS (4). In a study of 345 patients diagnosed with intestinal DLBCL, the patients were evaluated according to their treatments. Patients receiving chemotherapy following surgical resection were compared to patients receiving chemotherapy alone. Among patients with localized diseases, the relapse rate was lower in patients receiving chemotherapy following surgical resection than in patients receiving chemotherapy alone. The survival rate of 3 years following treatment was also significantly high in patients receiving chemotherapy following surgical resection $(\mathrm{p}<0.001)$ (2). Surgical resection and CHOP chemotherapy were performed in patients diagnosed with localized DLBCL in the ileocecal region. For these cases, especially, chemotherapy following surgical resection was more successful than chemotherapy alone (5). It should be noted that lymphoma increased the tendency toward thrombosis, and it should not be forgotten that delayed treatment can lead to thrombosis.

\section{Conclusion}

Our case submitted with an acute abdomen. His DLBCL, which transformed from MALT lymphoma, was diagnosed by biopsies. He was administered R-CHOP chemotherapy without surgical resection due to the diagnosis of diffuse involvement and high-grade lymphoma but died due to acute complications before completion of the chemotherapy. According to the type and extent of the GIS lymphoma, treatment options include $H$. pylori eradication, chemotherapy, and radiotherapy. It should be kept in mind that more successful results with chemotherapy following surgical resection are usually obtained in cases of detected localized lymphomas.

Informed Consent: The patient's consent could not be obtained because of death.
Peer-review: Externally peer-reviewed.

Author Contributions: Concept - G.Ç.; Design - C.K.; Materials - M.A.Ç.; Data Collection and/or Processing - C.K., M.K.; Analysis and/or Interpretation - G.Ç., N.Ç.; Literature Review - X.X., X.X.; Writing - G.Ç., C.K.

Conflict of Interest: No conflict of interest was declared by the authors.

Financial Disclosure: The authors declared that this study has received no financial support.

Acknowledgements: The authors would like to thank S. Delacroix for assistance with English editing.

Hasta Onamı: Hasta onamı hastanın ölümünden dolayı alınamamıștır.

Hakem Değerlendirmesi: Dış bağımsız.

Yazar Katkıları: Fikir - G.Ç.; Tasarım - C.K.; Malzemeler - M.A.Ç.; Veri Toplanması ve/veya İşlemesi - C.K., M.K.; Analiz ve/veya Yorum - G.Ç., N.Ç.; Literatür Taraması - xxx ; Yazıyı Yazan - G.Ç., C.K.

Çıkar Çatışması: Yazarlar çıkar çatışması bildirmemişlerdir.

Finansal Destek: Yazarlar bu çalışma için finansal destek almadıklarını beyan etmişlerdir.

Teşekkür: Yazarlar İngilizce redaksiyonlarından dolayı S. Delacroix’ye teşekkür eder.

\section{References}

1. Graff LG, Robinson D. Abdominal pain and emergency department evaluation. Emerg Med Clin North Am 2001; 19: 123-36. [CrossRef]

2. Kim SJ, Kang HJ, Kim JS, Oh SY, Choi CW, Lee SI, et al. Comparison of treatment strategies for patients with intestinal diffuse large B-cell lymphoma: surgical resection followed by chemotherapy versus chemotherapy alone. Blood 2011; 117: 1958-965. [CrossRef]

3. Kumar R, Xiu Y, Potenta S, Mavi A, Zhuang H, Yu JQ, et al. 18FFDG PET for evaluation of the treatment response in patients with gastrointestinal tract lymphomas. J Nucl Med 2004; 45: 1796-803.

4. Fleming ID, Turk PS, Murphy SB, Crist WM, Santana VM, Bhaskar NR. Surgical implications of primary gastrointestinal lymphoma of childhood. Arch Surg 1990; 125: 252-56. [CrossRef]

5. Chenal M, Molina H, Mendez V, Poole J, Parellada C. Uncommon presentations of non-Hodgkin's lymphoma: case 2 . Non-Hodgkin's lymphoma of the ileocecal region. J Clin Oncol 2003; 21: 565-67. [CrossRef] 